\title{
A First Approach to Distance Education for the Teaching of Business English in the Superior School of Energy and Mining
}

\author{
Dora Troitiño Díaz \\ Department of English for Specific Purposes, Superior School of Energy and Mining, Havana, Cuba \\ Email address: \\ dorita@eem.minem.cu \\ To cite this article: \\ Dora Troitiño Díaz. A First Approach to Distance Education for the Teaching of Business English in the Superior School of Energy and \\ Mining. Higher Education Research. Vol. 4, No. 2, 2019, pp. 26-29. doi: 10.11648/j.her.20190402.11
}

Received: March 26, 2019; Accepted: May 9, 2019; Published: June 4, 2019

\begin{abstract}
This paper aims at giving a general overview of the steps followed to implement the distance course for business English teaching in this school. There is an ever-increasing demand for English teaching and learning activities in Cuba as worldwide. The directors, managers, buyers and specialist from different branches of the Ministry of Energy and Mining need to prepare in this language, but there is a shortage of time for studying face to face and here it is where the distance education begins to play its important role in the preparation of the Ministry staff. This course is an alternative for higher rank officers at the Ministry to improve their business English skills. The course is set up in Moodle e-learning platform which eases the teaching process not only for the students but also the professor. The article provides with the course structure as well as an explanation of each one. It socializes some advantages and disadvantages found while implementing this course.
\end{abstract}

Keywords: Distance Education, English for Specific Purposes, Moodle

\section{Introduction}

This paper aims at introducing a new method implemented in the School of Energy and Mining for the teaching of Business English for the first time.

The importance of the English in the businesses exceeds to the countries that have it like official language. Many great companies and multinational corporations use this one like work language. The globalization has still more intensified the importance of the English like international language. The companies depend more and more on the electronic mail and Internet, means in which the dominant language is the English.

So, the importance of learning English cannot be overstated in an increasingly interconnected and globalized world. When a Japanese manager, a Mexican manufacturer and French customer meet in an international location, they communicate in English, since that has become the world language for business.

Most international business transactions, including emails, memos, reports and contracts, are written in English.

Cuba is not outside the last advances of the world and in accordance with the situation worldwide, it continues developing its teaching strategies to make them every day better and more effective.

In the speech pronounced by Army General Raúl Castro Ruz, President of the Councils of State and Ministers, during the opening session of the 4th CARICOM-Cuba Summit, Trinidad and Tobago, December 8, 2011, Year 53 of the Revolution. He stated that: "the next president must speak English. It is a necessity for our country, not only because of its proximity to our neighbors to the North; (...) [1] we are learning it not only given the importance of this language at the global level in all aspects, but also because we are a Caribbean people, and all the Caribbean people, as the Honorable Prime Minister of Trinidad and Tobago put it, must speak Spanish, and also English, in the case of the Spanish speakers."

So the Superior School of Basic Industry taking into account all the national and international scenery, and taking its mission as a basis: to provide the students with innovative tools and techniques to improve their performance in business management, focusing on personal development, fostering the collective values of the organization, carries out 
a wide plan of studies for the officials of the Ministry of Basic Industry. Within this plan, there are 4 English courses for different purposes. The Business Course Elementary and Pre- Intermediate levels are among them, and one of forms that have been implemented since last year is through distance education.

This initiative was begun taking into account that some of the specialists, buyers and managers belonging to the Ministry most of the time have not the time to be face to face with the teacher in real classroom time. So as the school had already ventured some other courses through this via such as Management, Accounting, Quality management, the author of this paper decided to begin implementing the English course in special the one devoted to business matter through distance education.

\section{Moodle and the Business English Course}

The course was set up in Moodle as the school has as one of its international collaborators Basque Country University. They were in charge of teaching the professors of the school to work with this new method.

Moodle, the e-learning platform, is one of the most significant and successful projects in open source. Despite its success, with hundreds of thousands of people being taught by courses written in Moodle, as a product it is not well known. It offers an environment for experimentation in the classroom. It is also a development of existing classroom education, in which students can interact freely with actions proposed. The following are some of the platform's key features:

1. It creates a favorable learning environment that works on a modular basis, in which it is very simple to introduce objects and updates.

2. Its interface enables resources to be created and managed dynamically and simply.

3. Learning is based on experience and exercises.

4. Many of the elements that are created on the platform can be easily reused.

5. It encourages collaboration and communication between users. [2].

The Moodle (Modular Object-Oriented Dynamic Learning Environment) is a course management system (CMS) designed to help teacher create e-learning courses. It is a modular system and offers considerable flexibility by being able to add or remove functionalities at many levels.

It offers a virtual environment, which the user can access using a web browser under any operating system. It is a flexible, highly visual, intuitive interface. In "virtual classrooms", the teacher can create consolidation or self assessment exercises, as well as collaborative areas for trying out tools, simulations and other activities. It is worth highlighting its synchronous tools (chat) and asynchronous tools (forums and internal messaging), which help with tutoring.
There is currently a lot of talk about Web 2.0 as a set of collaborative services, easy-to-use and share, which facilitate communication and provide simple work environments: blogs, wikis, discussion groups, social networking, etc. The majority of the facilities offered by Web 2.0 are also present in Moodle, given that this platform uses tools such as tags and blogs, where work groups are established. [3].

It is important to know how to use Moodle on a day-to-day basis. It is not just a question of inserting content or leaving the relevant theory module on the platform. If that is how we use Moodle, the course will not work. It is vital that the teacher works with it dynamically and that there is continuity between the work done inside and outside the classroom. It is essential for the role of the teacher to be tutorial and dynamic, not just passing on content but acting as a key stimulus for the students [4].

As it was before mentioned this e-learning platform was first used for the teaching of English in the Superior School of Basic Industry last year. The course began in March with 15 students registered all of them works in the different enterprises belonging to the Ministry of Basic Industry, most of them do not live here in Havana as it is difficult for them to access to face to face courses in the school they have registered this one.

The course specializes on business issues. It is a two- level foundation course for people who need to work in English as part of their job.

As a first experience the course has begun with the elementary level. This one does not assume that students are familiar with the grammar structures and business vocabulary presented. The course progresses at a steady elementary level and students are not asked to attempt tasks outside their linguistics abilities.

At this point it is good to clarify that all the students registered in this course are postgraduate ones.

\subsection{Structure of the Course}

Business Focus Elementary has twelve units built around a key functional area, such as describing yourself and your job or asking for help and advice. Each unit in the Student's book is divided into six sections, most of which also appear in the other components of the course. The six sections are:

Focus on Words

Each unit begins by looking at the key vocabulary relating to the unit topic. The vocabulary is presented in a variety of formats and is used and recycled throughout the rest of the unit. The section ends with a Key Words box for quick and easy reference. Students (Sts) can review and practice this vocabulary in their own time with the listening files and the workbook is provided to them. The vocabulary chosen is non-specialist and will appeal to all business English Sts.

Focus on Grammar

Here it is presented an item of grammar related to the theme of the unit throughout a realistic business context. Key grammar boxes are provided within the units of the Sts' book for quick reference and at the end of the Sts' book, there is more detailed and extended language reference section with 
extra practice exercises.

So Sts can review the grammar with exercises in the workbook. On the Cd-Rom short video clips are found from Big City I showing the grammar being used in a realistic context.

\section{Focus on Expressions}

This section introduces phrases and functional expressions to help sts in their daily work. Many of the expressions are presented through listenings and conversations, and practiced through role-play. Quick reference is provided in the Sts' book with Key Expressions boxes. Extra interactive practice is available to students on the $\mathrm{Cd}$-rom with a listen-recordplayback facility.

\section{Focus on Communication}

This section emphasizes on fluency and confidencebuilding. As well as speaking practice through various tasks carried out in class time (the ones previously arranged with the professor). This section also offers a variety of writing tasks based around emails.

\section{Focus on Business Issues}

This final focus, found in the sts' book, takes a broader look at the world of business through extended listening and fluency work. Sts have the opportunity, even at this low level, to express opinions on a variety of issues, and gradually build their confidence through well- structured mini discussions and debates.

\section{End-of Unit-Quiz}

As a final round up and review, Sts are going to check their progress with a quiz. It can be completed on their own or in pairs. The aim is not to test their knowledge, but to review what they have learnt, or find out what they need to review. The workbook includes a variation on the quiz in the form of a puzzle - crosswords, words games, etc-for them to review language from the unit in their own time.

Once the student enters our web site, he has to click on Moodle to enter the English course. He has a user's name and a password previously given to them by the net administrator to have full access to the course.

All the study materials, videos, listening and $\mathrm{Cd}-\mathrm{Rom}$ are put in the CMS for the students to download them as the first step. Here they will find the instructions for the course as well as the methodology the professor in charge is going to use.

Afterwards the different modules are developed into different lessons. There is a complete lesson devoted to each topic; it means that every unit has a lesson for Focus on Words, on Grammar, on Expressions, on Communication etc. The lesson is prepared as if it was a direct conversation with the students, and it is written in different colors to try catching the students' attention as much as it could be.

The teacher assigns different homeworks for them to upload them to the site in the place which is signaled for them. There are some of them which are specially evaluated for the teacher due to the importance of the topic treated.

There are several Discussion Forums opened, taking into account some themes that could be difficult or controversial for them. There, they could leave their views, questions or answers to another student who can interact through this space. Forums are always opened for suggestions or new information the students or the teacher may find about the topic which is in it.

The teacher has one day at the week for students consult their questions or interchange views about the lesson discusses that week. The teacher announces the hours she is going to be available on the site in advance for the students to know and be in contact with her as much as they need. It could be done through the chator the instant email it posses.

After the first six units of the course, the students have a face to face lesson with the teacher and the rest of the students. This one serves to practice and focus on their communication. The lesson is mainly for oral communication, and for them to clarify all the questions before the test.

There is an oral and written evaluation after unit 6 and another one after unit 12 the final unit of the course. Almost always there is more than one lesson, two or three before the test. For this reason they would be in the school for a week.

The teacher has included among the lessons of the site an interactive grammar exercise which comes with the course. This one allows the students to score themselves according to grammatical content dealt in the unit, promoting their self evaluation.

If there is a key topic which is going to be difficult for them, the teacher upload extra reading materials for them, and assigns some exercises for it. This was done for instance with the telemarketer's theme.

\subsection{Some Advantages and Shortcomings Found in the Road}

The use of this CMS in the School of Energy and Mining from the author's point of view has been of great utility. It has facilitated the students from Havana city and from other provinces to access to English learning. These are studentsworkers who sometimes due to work pressure cannot attend school part time to receive the courses. That is why Moodle has opened them a wide range of opportunities.

Moodle combines many different tools and teaching approaches under one roof. In the simplest case, Moodle installation provides only prefabricated educational materials for download, for example in the form of PDF files, presentations, word format or multimedia data. The integrated course and subscriber management ensures that registered users can quickly find and navigate the material provided uniquely for them. At this point it is important to highlight that the server in which the platform is set up and the broadband are crucial. Sometimes the students' navigation becomes difficult or slower due to the characteristics of both in their places of work.

Besides, while animations, video clips and podcasts can be integrated into the course, Moodle itself does not include the tools to produce them.

Students' knowledge can be tested using a number of different testing procedures, including multiple-choice among forms and gap texts. Existing online courses can be 
imported, including material in the SCORM format, a format supported by many learning tools for the exchange of structured content.

It must also be said that the more students that access the platform, the slower the system becomes, the amount of registered students in the case of English is 15 but there are other courses set in this platform so this can be troublesome for students when they are trying to take quizzes or tests, or just simply trying to access the course content. The website can also shut down on occasion, blocking the opportunity for students to access course materials.

This has been a constant problem and in the case of students of Havana has been solved because they have the opportunity to come to school to get the materials of the course. On the other hand, sometimes students from other provinces came to Havana once at the beginning to copy the heaviest materials such as listening activities, videos and CDROMs. But this has been one of the most frequent reasons for them to quit on the course.

In addition, Moodle students frequently complain about the troubles they experience with customizations. In order to perform efficient customization, you are going to need to know how to program and have some type of knowledge when it comes to coding.

The course also is insufficient for developing oral skills on the students, though the activities are assigned there is no way of checking this. That is why, the teacher has decided the face to face encounters but they are not sufficient yet.

\section{Conclusions}

The above describes the efforts by the School of Energy and Mining and teachers to improve the educational quality of teaching and learning by applying new technologies such as e-learning.

Although there are some drawbacks, it attempts to emphasize a certain number of advantages, for example, an opportunity for distance learning, which undoubtedly increases the quality of education and goes beyond traditional ways of teaching and learning, and thus extends further possibilities of learning.

As far as language teaching is concerned, modern information technologies do offer challenging ways of teaching and learning, such as easy access to study materials, individual pace, time and place of studying or almost immediate feedback on writing with email tutorial support. These benefits are, however, a partial solution for learners who need to develop speaking skills as it has been mentioned before in the paper.

\section{References}

[1] Castro, Raúl. Discurso pronunciado por el presidente Raú Castro en la reunión del CARICOM, 2011. Disponible en: www.cnctv.icrt.cu/.../discurso-pronunciado-por-raul-en-la-vicumbre-caricom-cuba.

[2] Cech, P. and B. Klímová. (2002). Formal versus Informal Written Business English. http://oliva/SCRIPT/TBE/scripts/ serve-work (accessed 11.12. 2011).

[3] Dougiamas, M. (2003) Moodle: Using Learning Communities to Create an Open Source Course Management System, aace.org.

[4] Foster, H. y Cole, J. (2007) Using Moodle: Teaching with the popular open source course management system. Edit. O’Reilly. $2^{\mathrm{a}}$ edición.

[5] Amudsen, C. (1993). Evolución de la teoría sobre la educación a distancia. Universidad Nacional Autónoma de México. Material en versión digital traducido por Jorge Méndez.

[6] Baños Sancho, J. (2007). La plataformaeducativamoodle. creacion de aulasvirtuales. Manual de consultapara el profesorado (version 1.8). IES Satafi, GETAFE.

[7] Kirner, T. G., Custodio, O, C. A., Kirner, C. (2008) "Usability Evaluation of the Moodle System from the Teachers' Perspective", IADIS International Conference e-Learning, available at: http://www. iadis.net/d1/final_uploads/200805L048.pdf.

[8] Lee, C., George Jor, G., \& Lai, E. (2005). Web-based Teaching and English Language Teaching: A Hong Kong Experience, Hong Kong: The Chinese University Press.

[9] Miranda Justiniani, A. y Yee Seuret, M. (1992). Antecedentes y desarrollo del programa de educación a distancia en Cuba: la enseñanza dirigida. En: CADE. Journal of Distance Education/Revue de l'enseignement à distance. Vol. VII, No. 3.

[10] Moodle website (2010) http://www.moodle.org.

[11] Moodle-docs (2010) MOODLE Documents Web Site, http://docs. moodle.org/en/Philosophy.

[12] Rice, W. (2006) Moodle e-learning course develoment. Packt publishing. Birmingham. Universitat Rovira I Virgili. (2007) Videos demostración de moodle. Tarragona.

[13] SangráMorer, A. (2002). Educación a distancia, educación presencial y usos de latecnología: una tríada para el progreso educativo. Disponible en: http://edutec.rediris.es/Revelec2/revelec15/sangra.pdf.

[14] Vílchez Quesada, E. (2006). Entornos de aprendizaje virtual. Disponible en: www.cientec.or.cr/matematica/pdf/P3-Vilchez.pdf

[15] VerdeciaCarballo, E. (2007). Algunos fundamentos filosóficos y psicológicos de latecnología educativa. En Revista Electrónica de Tecnología Educativa, No. 23.

[16] Vicent, A. (2008) Mapas Conceptuales de Moodle. 